\title{
INHIBITIVE EFFICIENCY OF ZINC ORGANO AMINO PHOSPHATE FOR THE CORROSION OF $\alpha$ - BRASS IN 0.5 M SULPHURIC ACID SOLUTION.
}

\author{
الكفانة المهبطية للمركب العضوى ZOAP على ععلية تآكل سبيكة النحاس الأصفر في سحلى \\ هامض لاكبريتد
}

F.N. El-Sabbahy* and M.I. Abbas**

* Lecturer ** Protessor

Metallurgical Engineering Department, Faculty of Pet. \& Min. Engineering, Suez, Egypt.

أجريث التجارب لازئسة ميكانبكية عملية التآكل نسبيكة التحاس الأصفر (70/30) فى

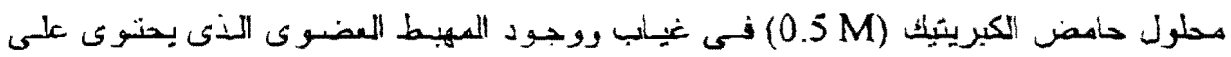

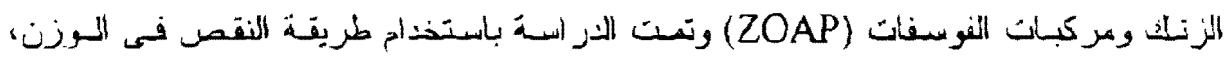

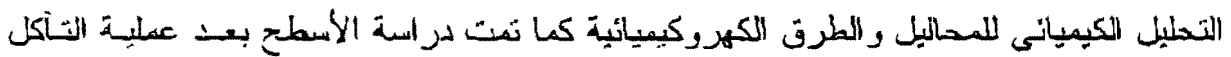

$$
\text { باستختام الميكروسكوب المضونى و التحليل الطيفى باستخدام الأثعة السبينية. }
$$

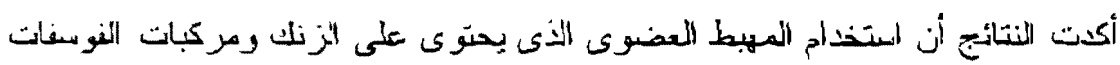

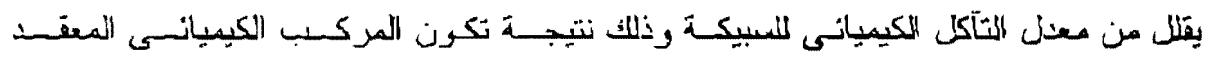

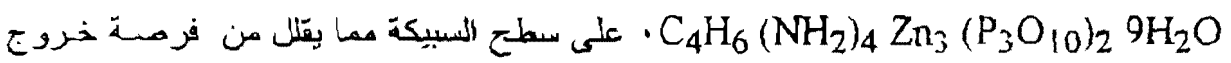

Abstract :

A study has been made to investigate the mechanism of dezincification and elelctrochemical behaviour $70 / 30$ brass in sulphuric acid in absence and presence of Zinc Organo Amino Phosphate (ZOAP) inhibitor using the weight loss method, solution analysis and eiectrochemical technique. Attacked surfaces were analyzed by optical metallography and $X$-ray analysis.

Results showed that ZOAP inhibitor is able to minimize the rate of dezincification due to the formation of a $\mathrm{C}_{4} \mathrm{H}_{6}\left(\mathrm{NH}_{2}\right)_{4} \mathrm{Zn}_{3}\left(\mathrm{P}_{3} \mathrm{O}_{10}\right)_{2}$. $9 \mathrm{H}_{2} \mathrm{O}$ complex coinpound on the metal surface. 


\section{Introduction :}

In the field of non-ferrous alloys, the subject of dealloying is of current interest because its scientitic as well as industrial applications. Dezincification is one of the well - known de-alloying process by ineans of which brass loses the valuable physical and mechanical properties leding of the total failure of stricture (1). Dezincification may take place either in localized regions (plug type) or uniformally over the whole surface (layer type) $(2,3)$. Three mechanisms of dezincification (4) have been proposed :

(i) preferential dissolution of zinc from the alloy.

(ii) simltaneous dissolution of copper and zinc followed by the redeposition of spongy copper, by cathodic reduction of cupric ions in solution, on the surface of the alloy.

(iii) dezincification by both the above mechanisms operating simultaneously.

Sugawar and Ebiko ( 5 ) have studied the dezincification of brasses by means of a potentiostat and an electron probe microanalyser and observed that the electrochemical behaviour of the $\alpha$ and $\alpha+\beta$ phases of brasses are essentially sinilar to those of copper in $3.5 \% \mathrm{NaCl}$ solution. They have reported that the dezincification is mainly due to the redeposition of copper. Langenegger and Robinson (6) observed a linear relationship between the rates of dezincification and specimen potential, and they have supported the preferential dissolution of zinc theory. Abbas (7) investigated the effect of temperature on the dezincification and corrosion of $70 / 30$ brass in $0.5 \mathrm{M} \mathrm{H}_{2} \mathrm{SO}_{4}$ and reported that dezincification of 70/30 brass takes place by different nechanisms depending on temperature. In general, $\mathrm{NaCl}, \mathrm{HNO}_{3}, \mathrm{HCl}$ and $\mathrm{H}_{2} \mathrm{SO}_{4}$ sblutions have been used to stidy the dezincification of brasses.

Many organic compounds have beell used as corrosion inhibitors for brasses in different media, of theses zinc organo amino phospluate. (ZOAP), has shown a greater inhibitive efficiency when used in water treatment for heat exchangers.

Investigation of dezincification and electrochemical behaviour of brasses in $\mathrm{H}_{2} \mathrm{SO}_{4}$ has the practical applications of estimating the corrosion properties of heat exchangers which operate in atomospheres contaminated with $\mathrm{SO}_{3}(7)$. Thus the present investigation is concerned with the study of the mechanism of dezincification of $\alpha$-brass and the nuhibitive action of Zinc organo amino phosphate (ZOAP) on the conosion rate of $\alpha$-brass in $0.5 \mathrm{M} \mathrm{H}_{2} \mathrm{SO}_{4}$ solution. 


\section{Experimental :}

To study the mechanism of dissolution of brass in $0.5 \mathrm{M} \mathrm{H}_{2} \mathrm{SO}_{4}$ solution and to study the effect of inhibitor, two sets of experiment were done.

a) Study of the corrosion and inhibition behaviour by weiglt loss method and solution analysis to detennine the concentrations of $\mathrm{Cu}$ and $\mathrm{Zn}$ in solution.

b) Study of electrochemical behaviour of brass in $0.5 \mathrm{M} \mathrm{H}_{2} \mathrm{SO}_{4}$, with and without inhibitor, with the help of a poteutioscan.

\section{Determination of inhibitive efficiency :}

Sample of cylinderical shape, 1.5 and $1 \mathrm{~cm}$ in diameter and beight respectively, were cut from a commercial grade brass bar (70 Cu $-29.9 \mathrm{Zn}$ - $0.07 \mathrm{Fe}-0.03 \mathrm{~Pb}$ ). A small hole was drilled at the upper edges of the samples for hanging them with nylon thread in the solutions. The samples were polished, successively with 400,500 and 600 grades of emery papers and then throughly cleaned with water and acetone. The experiments were conducted in $200 \mathrm{ml}$ conical flask containing $150 \mathrm{ml}$ of $0.5 \mathrm{H}_{2} \mathrm{SO}_{4}$ and with $0.0,0.2,0.5,1.2 \mathrm{ml} /$ liter concentration of inhibitor. The weight losses were determined after removing the corrosing products from the specimens by immersing them in $15 \% \mathrm{HCl}$ for $5 \mathrm{~min}$ and then washing them throughly with distilled water and drying. All experiments were carried out at $25 \pm 2{ }^{\circ} \mathrm{C}$. Inlubitive efficiency was caluculated using the equation

$$
E=\frac{a-b}{a} \text { X } 100 \%[2]
$$

Where :

$\mathrm{E}=$ percentage inhibitive efficiency.

$\mathrm{a}=$ weight loss in $0.5 \mathrm{H}_{2} \mathrm{SO}_{4}$ solution

$\mathrm{b}=$ weight loss in $0.5 \mathrm{H}_{2} \mathrm{SO}_{4}$ solution containing the inhibitor.

\section{Solution analysis :}

Solutions were analysed with A - 475 atomic absorption spectrometer. The instrument was standarized using solutions of known concentration, a minimum of 10 readings for each analysis was taken and the average value has been reported. The dezincification factor $(Z)$ is defined by [2] .

$$
Z=\frac{R_{S}}{R_{a}}
$$

Where :

$$
\mathrm{R}_{\mathrm{S}}=\mathrm{Zn} / \mathrm{Cu} \text { ratio in solution. }
$$


$R_{a}=Z_{n} /$ Cu ratio in the alloy.

The $Z_{n} / \mathrm{Cu}$ ratio $\left(R_{\mathrm{s}}\right)$ in the solution was deternined by chemical analysis of the solution and the ratio of $\mathrm{Zn} / \mathrm{Cu}$ in the alloy $\left(\mathrm{R}_{\mathrm{a}}\right)$ obtained from their percentage weights in the alloy.

\section{Open circuit potential and polarization measurements :}

A wenking potentioscan model POS - 73 was used for monitoring the corrosion potential of the brass as well for potentiostatic ploarization measurements. The open circuit potential of brass against a saturated calomel electrode was continuously monitored using the potentioscan. Potentiostatic polarization curves were obtained manually starting from the steady potential. A platinum comnter electrode was used.

\section{Surface analyses of attacked metal :}

Corroded metal was analysed by two methods: optical metallography and $\mathrm{X}$-ray diffraction analysis.

\section{Results:}

\section{Inhibitive efficiency:}

From table $\{I$ ) and Fig. (I) it is clear that ZOAP gives $86 \%$ efficiency at its optimum concentration of $1 \mathrm{nn} / \mathrm{L}$. In Fig. 2 the percentage inhibitive efficiencies of ZOAP inhibitor is plotted as a function of immersion period. The maximum efficiency was reached after 24 hrs unumersion, after which the efficiency decreased [Fig.(2) and table \{II\}] This may be due to the dissolution of a complex protective film from the metal surface. The lower inhibitive efficiency of the compounds prior to 24 hrs may be due to the presence of an imperfection complex protective film on the surface of the metal not capable of inhibiting the dissolution of zinc and copper ions from brass.

The effect of inhibitor at different concentrations on copper and zinc dissolution is shown in Fig.(2). ZOAP mainly inhibits zinc dissolution, it is not very effective in the case of copper whicl shows that ZOAP is able to minimize the rate of dezincification.

\section{Dezincification:}

Equation (2) was used to calculate the dezincification factor $(Z)$ from the solution analysis data obtained for solution containing $1 \mathrm{ml} / \mathrm{L}$ ZOAP. Fig. (3) shows the dezincification factors obtained for without and witl ZOAP containing $1 \mathrm{ml} / \mathrm{L}$ solutions. For free ZOAP solutions the dezincification factor is high in the initial period due to the preferential dissolution of zinc, which gradually decrease with time until $Z$ becomes 
unity, suggesting that botly copper and zinc ions are going into solution at the same rate (7). On the other hand solutions containing $1 \mathrm{ml} / \mathrm{L}$ ZOAP shows a lower dezincification indicating a much low dissolution of zinc.

\section{Open circuit potential:}

The corrosion potential of brass $70 / 30$ in $0.5 \mathrm{M} \mathrm{H}_{2} \mathrm{SO}_{4}$ solution without and with $0.2,0.5,1$ and $1.2 \mathrm{ml} / \mathrm{L} Z \mathrm{ZOAP}$ at $25 \pm \mathrm{C}$ was recorded as a function of time and results are given in Fig. (4). This shows that the potential, irrespective of inluibitor concentration, shifts with time to the nobbler direction before attaining a stable, steady maximum value. Generally initial as well as steady potentials became more positive as the content of ZOAP increased up to $1 \%$. However $1.2 \mathrm{ml} / \mathrm{L}$ more or less shows the same effect as $1 \mathrm{ml} / \mathrm{L}$ ZOAP.

The general shift of steady state potential in the nobbler direction indicates greater polarization of the anodic than cathodic processes at the brass surface with increasing ZOAP concentrations.

\section{Potentiostatic polarization :}

The anodic polarization and the cathodic polarization curves in the absence and with presence of ZOAP inhibitor at different concentrations are slown in Fig. (5) and Fig. (6). The polarization curve of $\alpha$-brass in 0.5 $\mathrm{M} \mathrm{H}_{2} \mathrm{SO}_{4}$ solution without inhibitor shows two passive regions, primary and secondary, which are suggested to be due to the formation of cuprous oxide and cupric oxide films respectively [7]. Moreover Fig.(5) shows that as the inhibitor concentration is increased up to $1 \% \mathrm{ml} / \mathrm{L}$ anodic polarization curves shift towards lower current densities. ZOAP shows maximum passivation in the prinary passivation region and above this region it does not inhibit the corrosion of brasses. It is supposed that ZOAP fonns a stable complex with zinc and thus gives protection in the prinary passivation region hence ZOAP is not effective inhibitor in the higher potential region. The small indication of a secoudary passivation region obtained in the presence of ZOAP may be due to the formation of $\mathrm{CuO}$ film. The corrosion current density computed by a rough extrapolation of cathodic and anodic curves indicates that the corrosion current decreases with increasmg the ZOAP in $0.5 \mathrm{M} \mathrm{H}_{2} \mathrm{SO}_{4}$ solution table \{III\}. Generally the results obtained by potentiostatic polarization technique are in good agreement with those obtained by weight loss method. 


\section{$\mathrm{X}$-ray analysis:}

Fig. (7) shows the result of X-ray diffaction analysis of brass surface exposed to solution without and with ZOAP inhibitor ( $1 \mathrm{~m} / / \mathrm{L})$ for 24 irrs. It is clear that a complex compound of $\mathrm{C}_{4} \mathrm{H}_{6}\left(\mathrm{NH}_{2}\right)_{4} \mathrm{Zn}_{3}\left(\mathrm{P}_{3}\right.$ $\left.\mathrm{O}_{10}\right)_{2} \cdot 9 \mathrm{H}_{2} \mathrm{O}$ is formed on the metal surface.

\section{Microscopy:}

In the presence of ZOAP inhibitor a thin black film has been observed on the surface of the specimens. This confirms that the inthibition is due to the formation of some complex film with metal ions.

\section{Discussion:}

Gupta and others [2] showed that the organic inhibitors act as proton acceptors, releasing $\mathrm{H}^{+}$ions into the sulphuric acid solution and forming an organo inetailic complex layer with the metal ions on the surface of the metal, thus inhibiting the corrosion.

In ZOAP, the Amino group acts as the reaction center, on which is formed a complex with the metal ions. The prinary passivation in the presence of inhibitor is supposed to be due to the formation of cuprous oxide film along with a stable zinc complex and, on further increasing the anodic potential the inhibitive effect of ZOAP becames insignificance. Generally, the dezincification factor decreases in presence of ZOAP.

The dissolution of $\alpha$-brass in $0.5 \mathrm{M} \mathrm{H}_{2} \mathrm{SO}_{4}$ solution without or with $\mathrm{Iml} / \mathrm{L}$ ZOAP is schematically represented in Fig. (8) which has been compiled with the help of publicated data $[2,7]$.

\section{Conclusion:}

From the present study the following conclusions can be drawn :

1- ZOAP is effective inlibitor for $70 / 30$ brass in $0.5 \mathrm{M} \mathrm{H}_{2} \mathrm{SO}_{4}$ solution and its inhibitive efficiency reaches maximun value of $86 \%$ at its optimum concentration of $1 \mathrm{~mL} / \mathrm{L}$.

2- The inhibitive action of ZOAP is due to the formation of a protective complex film mainly with zinc metal ions on the surface of the ailay.

\section{References:}

I- E. MATTSSON: Br. Corros. J., 1980, 15, 6.

2- PUSPA GUPTA, R.S.; CHAUDHARY, T.K.G.; NAMBOODHIRU AND PRAKASH: Br. Corros. J., 1982 17, 136.

3- L.P. COSTAS: Corrosion, 1974, 30, 167.

4- RH. HEIDERSBACK AND E VERINK: Corrosion, 1972, 28, 397.

5- H. SUGAWARA AND H. EBIKO): Corros. Sci., 1967, 2 513.

6- E. E. LANGENEGGER AND F.B.A. ROBINSON: Corrosion, 1969, $25,59$.

7- M.I. ABBAS: Br. Cortos. J.; 1991, 26, 273. 
Monsoura Engineering Journal (MEJ), Vol. 20, No. 2, June, 1995, M. 20.

Table (I): Effect of induibitor concentration on indibitive efficiency towards $70 / 30$ brass in $0.5 \mathrm{M} . \mathrm{H}_{2} \mathrm{SO}_{4}$ at $25 \pm 2^{\circ} \mathrm{C}$, after 48hrs.

\begin{tabular}{|c|c|c|c|c|c|c|c|}
\hline \multirow{2}{*}{$\begin{array}{l}\text { Inhibitor } \\
\text { concentration } \\
\mathrm{nL/L}\end{array}$} & \multirow{2}{*}{$\begin{array}{l}\text { Weight } \\
\text { Loss } \\
\text { urg }\end{array}$} & \multicolumn{2}{|c|}{ Solution analysis } & \multirow[t]{2}{*}{ Efficiency } & \multirow{2}{*}{$\begin{array}{l}\text { Dezincification } \\
\text { factor }(Z)\end{array}$} & \multicolumn{2}{|c|}{ Efficiency } \\
\hline & & $\begin{array}{l}\mathrm{Cu} \\
\mathrm{mig} / \mathrm{L}\end{array}$ & $\begin{array}{l}\mathrm{Zn} \\
\mathrm{mg} / \mathrm{L}\end{array}$ & & & $\mathrm{Cu}$ & $Z_{n}$ \\
\hline $\begin{array}{l}\text { [- Without inhbitor } \\
2-\text { With inhibitor } \\
\text { a- } 0.2 \\
\text { b- } 0.5 \\
\text { c }-1.0 \\
\text { d- } 1.2\end{array}$ & $\begin{array}{l}13 \\
8.5 \\
6.2 \\
1.8 \\
4.1\end{array}$ & $\begin{array}{l}42.7 \\
20.4 \\
16.3 \\
13.1 \\
19.0\end{array}$ & $\begin{array}{l}24.0 \\
8.5 \\
6.3 \\
3.2 \\
8.6\end{array}$ & $\begin{array}{l}-- \\
35 \\
52 \\
86 \\
68\end{array}$ & $\begin{array}{l}1.3 \\
0.97 \\
0.90 \\
0.57 \\
1.06\end{array}$ & $\begin{array}{l}52 \\
62 \\
69 \\
56\end{array}$ & $\begin{array}{l}65 \\
74 \\
87 \\
64\end{array}$ \\
\hline
\end{tabular}

Table (II): Variation with time of $\mathrm{Cu}$ and $\mathrm{Zn}$ dissolution from 70/30 brass in absence and presence of ZOAP inibitor.

\begin{tabular}{|c|c|c|c|c|c|c|c|c|}
\hline \multirow{3}{*}{$\frac{\text { Time }}{\text { hrs }}$} & \multicolumn{3}{|c|}{$0.5 \mathrm{M} \mathrm{H}_{2} \mathrm{SO}_{4}$} & \multicolumn{5}{|c|}{$1 \mathrm{ml} Z O A P \Omega$} \\
\hline & \multirow{2}{*}{$\begin{array}{c}\mathrm{Cu} \\
\mathrm{mg} / \mathrm{L}\end{array}$} & \multirow{2}{*}{$\begin{array}{c}\mathrm{Zn} \\
\mathrm{mg} / \mathrm{L}\end{array}$} & \multirow[t]{2}{*}{$\mathrm{Z}$} & \multirow{2}{*}{$\begin{array}{c}\mathrm{Cu} \\
\mathrm{mg} / \mathrm{L}\end{array}$} & \multirow{2}{*}{$\begin{array}{c}\mathrm{Zn} \\
\mathrm{mg} / \mathrm{L}\end{array}$} & \multirow[t]{2}{*}{$\bar{Z}$} & \multicolumn{2}{|c|}{ Eficiency } \\
\hline & & & & & & & $\mathrm{Cu}$ & $\mathrm{Zn}$ \\
\hline 2 & 2.6 & 8.29 & 12.0 & 1.6 & 3.69 & 5.38 & 39 & 55 \\
\hline 8 & 4.65 & 11.6 & 5.8 & 2.6 & 3.8 & 3.41 & 44 & 68 \\
\hline 16 & 14.4 & 18.6 & 3.01 & 6.7 & 4.3 & 1.18 & 53 & 82 \\
\hline 24 & 28.1 & 25.0 & 2.07 & 10.5 & 2.0 & 0.44 & 63 & 93 \\
\hline 36 & 51.2 & 38.7 & 1.76 & 20.9 & 3.2 & 0.35 & 59 & 92 \\
\hline 48 & 63 & 38.1 & 1.4 & 30.2 & 4.5 & 0.35 & 52 & 88 \\
\hline
\end{tabular}

Table (III): Effect of inhibitor concentrations on some electrochemical parameters towards $70 / 30$ brass.

\begin{tabular}{|c|c|c|c|c|}
\hline Series & $\begin{array}{c}\text { Inhibitor } \\
\text { concentration } \\
\mathrm{m} / \mathrm{L}\end{array}$ & $\begin{array}{c}\mathrm{I}_{\mathrm{corT}} \\
\mathrm{mA} / \mathrm{Cm}^{2}\end{array}$ & $\begin{array}{c}\mathrm{E}_{\mathrm{cor}} \\
\mathrm{mV} \text { (SCE) }\end{array}$ & $\begin{array}{c}\mathrm{i}_{\mathrm{crit}} \\
\mathrm{mA} / \mathrm{Cm}^{2}\end{array}$ \\
\hline 1- & $\begin{array}{l}\text { without inhibitor } \\
\text { ZOAP } \\
\text { (a) } 0.2 \\
\text { (b) } 0.5 \\
\text { (c) } 1 \\
\text { (d) } 1.2\end{array}$ & $\begin{array}{l}0.038 \\
0.025 \\
0.021 \\
0.018 \\
0.020\end{array}$ & $\begin{array}{l}-160 \\
-120 \\
-70 \\
+30 \\
+20\end{array}$ & $\begin{array}{l}2.5 \\
2.2 \\
0.52 \\
0.51 \\
0.60\end{array}$ \\
\hline
\end{tabular}




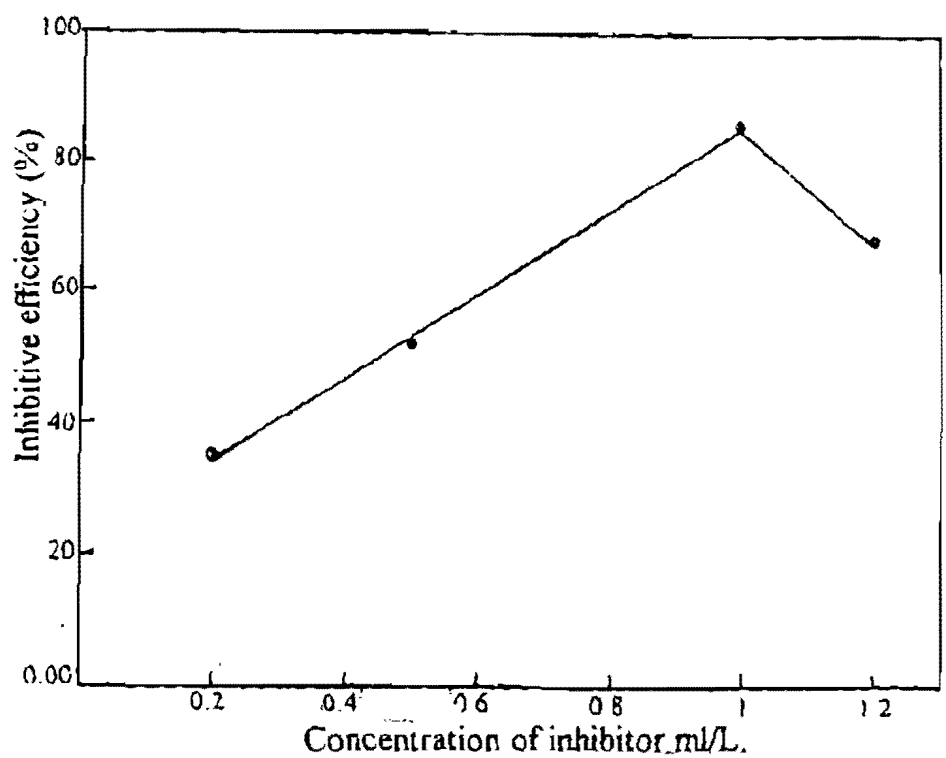

Fig 1:Effect of inhibitor concentration on inhibitive efficiency towards $70 / 30$ brass in $0.5 \mathrm{M} \mathrm{H}_{2} \mathrm{SO}_{4}$ solution at $25 \pm 2^{\circ} \mathrm{C}$ after $48 \mathrm{hrs}$

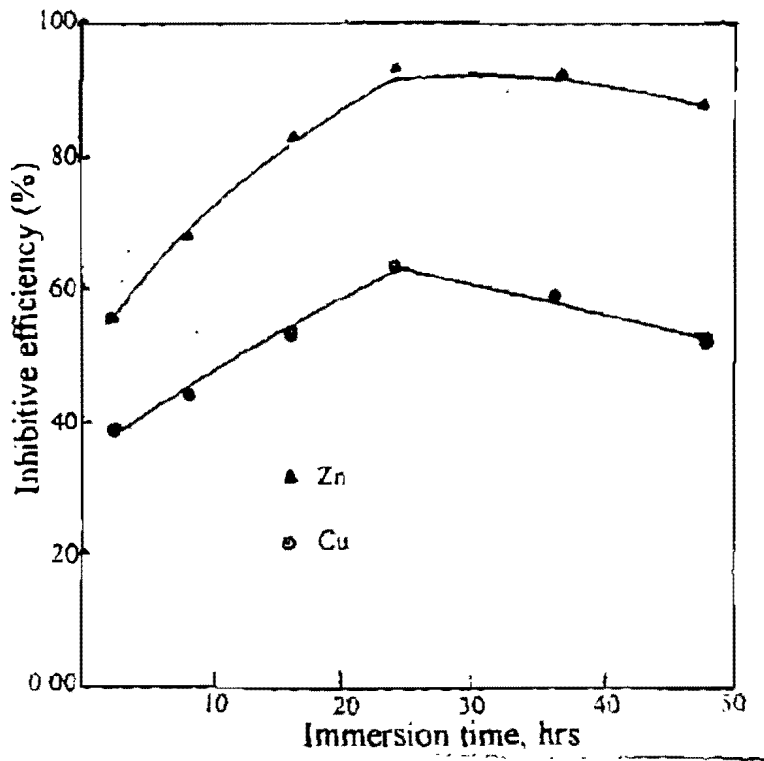

Fig. 2: Variation of inhibitive efficiency with immersion time towards $70 / 30$ brass in $0.5 \mathrm{M} \mathrm{H}_{2} \mathrm{SO}_{4}$ solution with $1 \mathrm{~m}$ inhibitor concentration at $25 \pm 2^{\circ} \mathrm{C}$. 
Mansoura Engineering Journal (MEJ), Vol. 20, No. 2, June, 1995, M. 22.

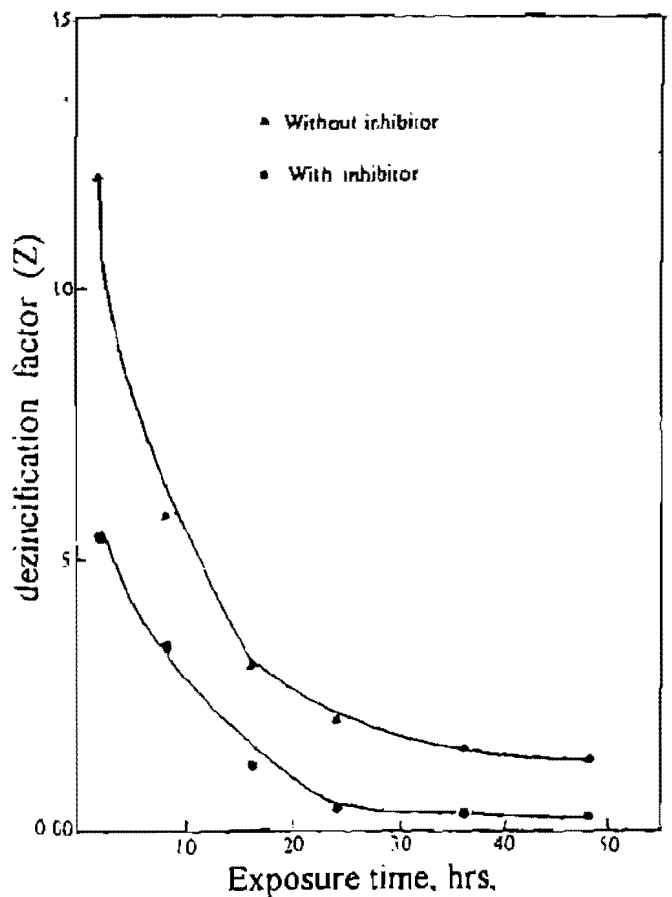

Fig. 3: Variation of dezincification factor (Z) with exposure time in $0.5 \mathrm{M} \mathrm{H}_{2} \mathrm{SO}_{4}$ solution without and with inhibitor $(1 \mathrm{ml} / \mathrm{L})$.

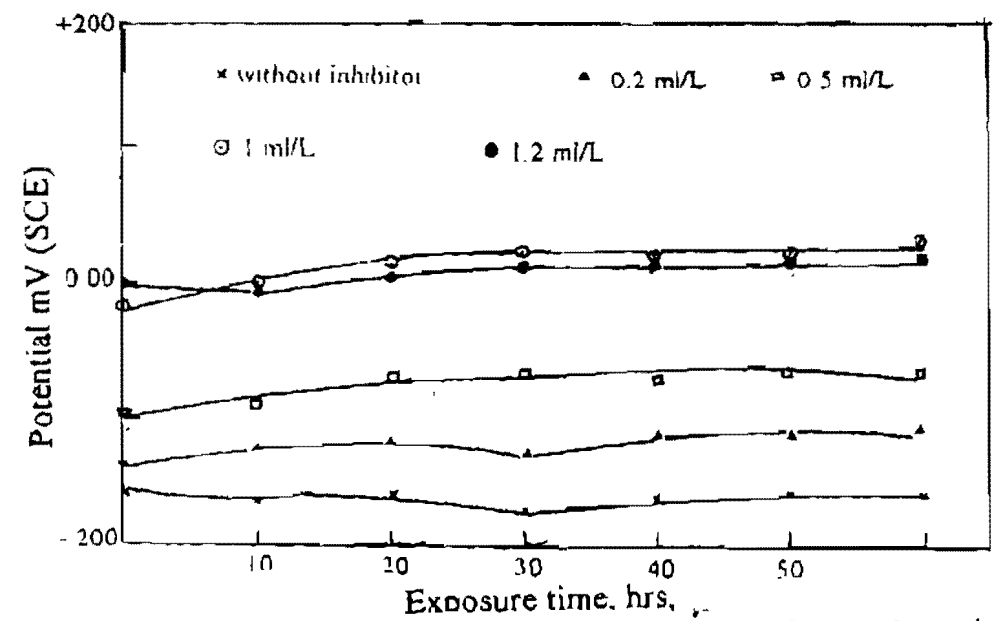

Fig. 4: Effect of exposure time on the corrosion potential of $70 / 30$ brass in $05 \mathrm{M}$ $\mathrm{H}_{2} \mathrm{SO}_{4}$ solution without and with different concentrations of inhibitor at $25 \pm 2$ ${ }^{\circ} \mathrm{C}$. 
M. 23. F.N. El-Sabbahy, M.l. Abbas

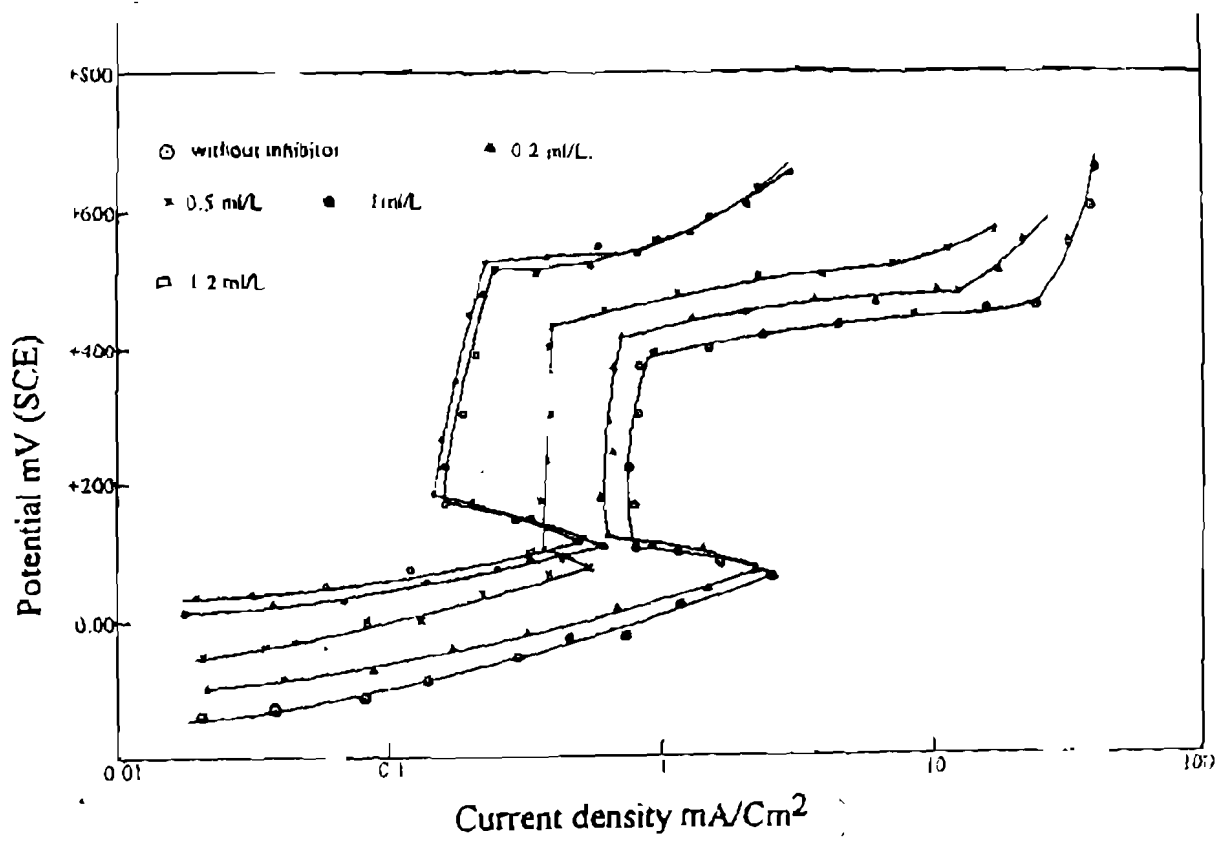

Fig. 5: Potentiostatic anodic polarization curves for $70 / 30$ brass in $0.5 \mathrm{M} \mathrm{H}_{2} \mathrm{SO}_{4}$ solution without and with different concentrations of inhibitor.

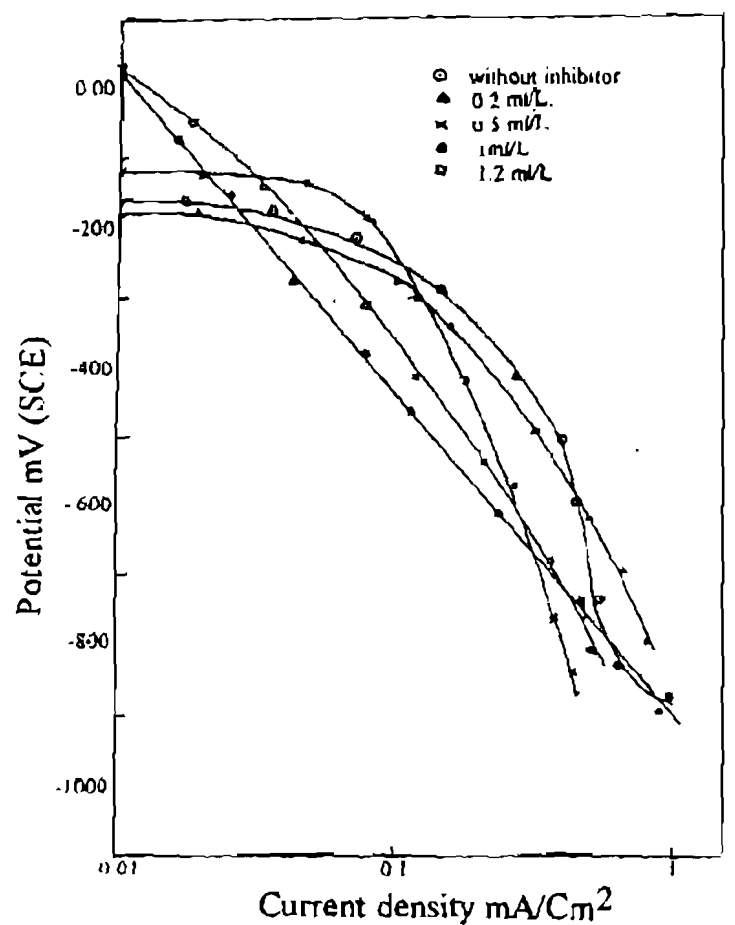

Fig. 6: Potentiostatic cathodic polarization curves for $70 / 30$ brass in $0.5 \mathrm{M} \mathrm{H}_{2} \mathrm{SO}_{4}$ solution without and with different concentrations of inhibitor. 
Mansourn Engineering Journal (ME.J), Vol. 20. No. 2, June, 1995, M. 24.

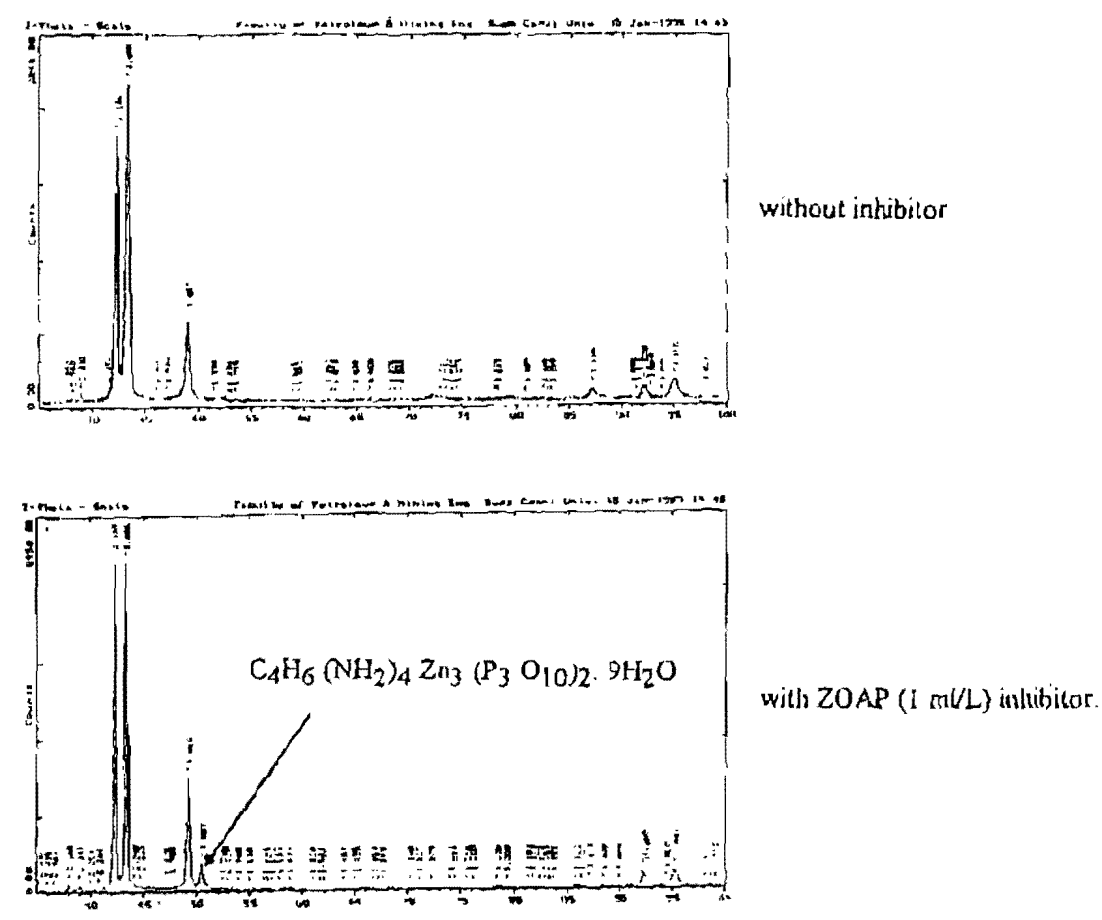

Fig. 7: X-ray analysis of $70 / 30$ brass surface exposed to $0.5 \mathrm{M} \mathrm{H}_{2} \mathrm{SO}_{4}$ solution without and with inhibitor $1 \mathrm{ml} / \mathrm{L}$ for $24 \mathrm{hrs}$ at $25 \pm 2^{\circ} \mathrm{C}$.

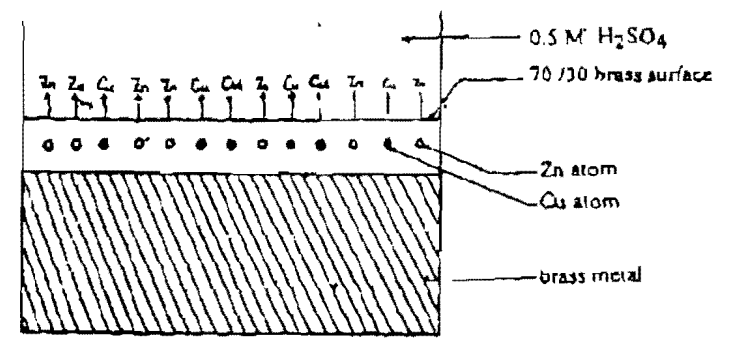

(a)

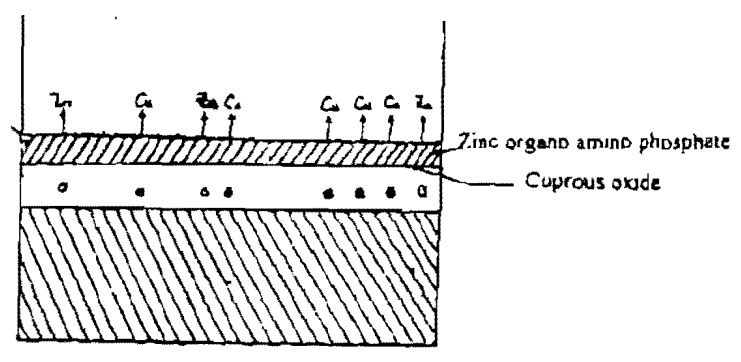

(b)

Fig. 8: Schematic diagrams showing mechanisin of dissolution of $\alpha$-brass in $0.5 \mathrm{M}$ $\mathrm{H}_{2} \mathrm{SO}_{4}$.

(a) without inhibitor (b) with ZOAP ( $\mathrm{mLL}$ ) inhibitor. 